\title{
PERAN CITRA MEREK MEMEDIASI PENGARUH KUALITAS PRODUK TERHADAP KEPUTUSAN PEMBELIAN
}

\section{Ida Bagus Dicky Darmajaya ${ }^{1}$ Tjok Gede Raka Sukawati}

\author{
${ }^{1,2}$ Fakultas Ekonomi dan Bisnis Universitas Udayana (Unud), Bali, Indonesia \\ E-mail: d.dickydarmajaya@gmail.com
}

\begin{abstract}
ABSTRAK
Penelitian ini dilakukan pada konsumen produk KFC di Kota Denpasar dengan jumlah sampel sebanyak 110 responden. Penentuan sampel menggunakan metode non probability sampling. Data dikumpulkan melalui kuesioner. Teknik analisis data yang digunakan adalah teknik analisis jalur (path analysis) dan Uji Sobel. Berdasarkan hasil penelitian yang dilakukan, ditemukan bahwa kualitas produk berpengaruh secara positif dan signifikan terhadap citra merek, hal tersebut berarti semakin baik kualitas produkmaka akan semakin tinggi citra merek. Kualitas produk berpengaruh positif dan signifikan terhadap keputusan pembelian, hal ini menunjukkan semakin baik kualitas produk yang dirasakan maka akan semakin tinggi tingkat keputusan pembelian. Citra merek berpengaruh secara positif dan signifikan terhadap keputusan pembelian, hal tersebut berarti semakin tinggi citra merek maka akan semakin tinggi tingkat keputusan pembelian. Citra merek mampu memediasi pengaruh kualitas produk terhadap keputusan pembelian, hal tersebut berarti citra merek memediasi pengaruh kualitas produk ke keputusan pembelian secara parsial.
\end{abstract}

Kata Kunci: kualitas produk, citra merek, keputusan pembelian

\begin{abstract}
This research was conducted on consumer of KFC product in Denpasar City with total sample counted 110 respondents. Determination of sample using non-probability sampling method. Data were collected through questionnaires. Data analysis technique used is path analysis technique and Sobel test. Based on the results of research conducted, it was found that product quality positively and significantly impact the brand image, it means the better the quality of the product the higher the brand image. Product quality has a positive and significant impact on purchasing decisions, it shows the better the perceived quality of the product, the higher the purchasing decision level. Brand image has a positive and significant impact on purchasing decisions, it means the higher the brand image, the higher the level of purchase decision. Brand image is able to mediate the effect of product quality on purchasing decisions, which means the brand image mediates the effect of product quality to partial purchasing decisions.
\end{abstract}

Keywords: product quality, brand image, purchase decision 
Ida Bagus Dicky Darmajaya dan Tjok Gede Raka Sukawati, Peran Citra Merek...

\section{PENDAHULUAN}

Makanan dan minuman tercatat sebagai salah satu potensi bisnis dengan tingkat pertumbuhan yang tinggi. Hal ini disebabkan makanan merupakan salah satu kebutuhan utama semua orang dari berbagai kalangan. Salah satu sektor yang sedang berkembang pesat saat ini adalah usaha makanan cepat saji. Makanan cepat saji merupakan makanan dan minuman yang dapat dikonsumsi secara langsung, seperti pizza, sandwich dan makanan berbasis ayam. Makanan cepat saji adalah alternatif makanan yang cepat dengan harga terjangkau dan tersedia untuk dimasak dirumah. Makanan cepat saji memiliki beberapa kelebihan yaitu penyajiannya yang cepat sehingga tidak menghabiskan waktu yang lama dan dapat dihidangkan kapan dan dimana saja. Makanan adalah kebutuhan yang wajib dipenuhi, sehingga bisnis yang terkait dengan makanan terus berkembang, semakin hari semakin ramai. Seiring dengan tingkat kesejahteraan masyarakat, saat ini banyak jenis restoran yang bermunculan, mulai dari kafe tenda, restoran tradisional, fast food sampai restoran dengan makanan-makanan asing (western). Berkembangnya bisnis restoran, selain karena faktor tingkat kesejahteraan, terkait dengan perilaku konsumen yang suka makan di luar rumah. Fast food semakin diminati karena dianggap dapat memenuhi kebutuhan konsumsi bagi masyarakat yang sibuk dengan pekerjaannya dan memiliki keterbatasan waktu (Mufidah, 2012).

Fast food disajikan secara praktis dengan waktu persiapannya yang singkat, sehingga dapat menghemat waktu untuk makan ketika seseorang memiliki aktivitas yang padat. Harga yang ditawarkan oleh produsen fast food cukup terjangkau jika dibandingkan dengan harus mengolah bahan makanan yang dibeli sendiri. Menurut 
Mufidah (2012), kesibukan orang tua untuk berkarir menyebabkan mereka tidak memiliki waktu untuk menyiapkan makanan di rumah, sehingga lebih memilih untuk membeli makanan di luar rumah yang tentunya dapat diperoleh dengan waktu yang singkat. Mayoritas masyarakat Indonesia lebih menyukai berkunjung ke outlet cepat saji dibandingkan jenis restoran lainnya ketika ingin makan di luar rumah. Survei terbaru dari Master Card bertajuk Consumer Purchasing Priorities menyatakan bahwa sebanyak 80 persen masyarakat di Indonesia lebih memilih untuk bersantap di outlet cepat saji, diikuti oleh pusat jajanan atau food court sebanyak 61 persen, dan restoran atau kafe kelas menengah sebanyak 22 persen, dan hanya sekitar 1 persen yang memilih mengunjungi restoran untuk jamuan makan resmi (fine dining). Anang Sukandar selaku CEO Indonesia Franchise Association (IFA), meningkatnya pelaku bisnis waralaba fast food pada Tahun 2017 menyebabkan persaingan di industri ini menjadi semakin kompetitif. Persaingan yang kompetitif ini dialami oleh Kentucky Fried Chicken, McDonald's, Hoka Hoka Bento dan Pizza Hut. Menurut Health Education Authority (2002), konsumen fast food rata-rata berusia 15 sampai 34 tahun.

Berdasarkan hasil survei awal yang dilakukan terhadap 25 orang responden yang pernah melakukan pembelian di KFC di Kota Denpasar, diperoleh bahwa 62,5 persen responden tidak tertarik karena citra merek yang ditawarkan terhadap variasi kualitas produk KFC yang dapat memenuhi kebutuhan makanan dengan baik belum sesuai dengan harapan yang dirasakan konsumen yang secara otomatis berdampak pada keputusan pembeliannya. Kondisi ini mengakibatkan konsumen dihadapkan pada berbagai pilihan produk dengan merek dan kualitas yang bervariasi, kemudian 
Ida Bagus Dicky Darmajaya dan Tjok Gede Raka Sukawati, Peran Citra Merek...

konsumen senantiasa akan mencari nilai tertinggi dari produk-produk tersebut dan tentunya dapat membuat pelanggan merasa puas dengan produk (Masitha dan Heru, 2014).

Keputusan pembelian dijadikan dasar dalam mengembangkan sebuah produk yang baik. Penting bagi produsen untuk mengetahui faktor-faktor yang mempengaruhi keputusan pembelian (Putri, 2013). Kotler dan Keller (2008:234) menjelaskan bahwa perusahaan yang cerdas akan mencoba memahami sepenuhnya proses pengambilan keputusan pelanggan, semua pengalaman mereka dalam belajar, memilih dan menggunakan produk. Keputusan pembelian dipengaruhi oleh faktor citra merek yang positif, dengan adanya citra merek yang kuat dapat menyebabkan merek tersebut melekat dibenak konsumen (Andreani et al., 2012). Menurut (Aditya dkk,. 2012) keputusan pembelian adalah sebuah keputusan konsumen dalam membeli suatu produk setelah mempertimbangkan informasi, realitas serta layak atau tidaknya produk tersebut. keputusan pembelian konsumen dapat dilihat sebagai suatu proses dimana konsumen akan mengevaluasi produk dengan melihat kekuatan berbagai atribut produk dan citra yang dimiliki oleh produk tersebut (Oghojafor et al., 2012).

Citra merek memegang peranan penting dalam keputusan pembelian dimana perusahaan harus memiliki citra yang baik untuk menimbulkan minat beli pada konsumen dan berujung pada keputusan pembelian. Citra merek merupakan subvariabel yang kuat dalam perusahaan dan sangat penting dalam keputusan pembelian bagi konsumen (Nigam et al., 2011). Citra Merek adalah kesan yang dibuat dalam memori konsumen karena adanya keterlibatan konsumen dengan 
sebuah merek (Arslan, 2014). Brand image sebagai acuan sebelum konsumen melakukan pembelian (Lin, Nan-Hong and Bih-Syah Lin, 2007). Jalilvand (2012) mengungkapkan merek yang kuat dapat meningkatkan kepercayaan pelanggan pada produk atau jasa yang dibeli dan memungkinkan mereka untuk lebih memvisualisasikan dan memahami factor-faktor yang tak berwujud. Citra merek menurut Kotler dan Keller (2009:403) adalah persepsi yang dimiliki oleh konsumen saat pertama kali mendengar slogan yang diingat dan tertanam di benak konsumen. Citra merek adalah segala hal yang digambarkan oleh persepsi dan perasaan konsumen mengenai produk dan kinerjanya dan segala hal lainnya yang berarti konsumen (Kotler dan Armstrong, 2012:243). Alasan ini yang membuat perusahaan untuk memperkuat produknya agar tercipta citra merek yang positif dan melekat di benak konsumen. Hasil penelitian dari Purnamasari dan Murwatiningsih (2015) menyatakan bahwa citra merek secara positif dan signifikan memediasi kualitas produk terhadap keputusan pembelian konsumen. Koh dan Fang (dalam Yu et al., 2013) menghasilkan temuan bahwa persepsi konsumen terhadap citra merek memiliki dampak positif pada keputusan pembelian. Sedangkan penelitian yang dilakukan oleh (Nurhayati, 2017) mendapatkan hasil yang berbeda, dimana citra merek tidak memiliki pengaruh terhadap keputusan pembelian.

Konsumen menggunakan penilaian mereka dalam menentukan dan membuat keputusan mereka, terutama saat membeli produk yang berkualitas (Ackaradejruangsri, 2013). Menurut (Bhakar et al., 2012: 27) brand image yang baik adalah memberikan kualitas produk yang baik bagi konsumen. Menurut Kotler dan Armstrong (2008:272) kualitas produk (product quality) adalah karakteristik 
Ida Bagus Dicky Darmajaya dan Tjok Gede Raka Sukawati, Peran Citra Merek...

produk yang bergantung pada kemampuannya untuk memuaskan kebutuhan pelanggan yang dinyatakan atau diimplementasikan. Penelitian yang dilakukan oleh Indrayani (2013) memperlihatkan bahwa variabel kualitas produk memiliki pengaruh yang positif dan signifikan terhadap keputusan pembelian. Hasil penelitian penelitian yang dilakukan Sujito dan Huda (2012), menunjukkan bahwa kualitas produk memiliki pengaruh yang signifikan terhadap keputusan pembelian. Namun berbeda dengan penelitian yang dilakukan oleh Supriyadi dkk. (2016) Variabel kualitas produk tidak berpengaruh terhadap variabel keputusan pembelian.

Berdasarkan research gap tersebut, maka penelitian ini dimaksudkan untuk pengembangan studi dari berbagai penelitian yang telah dilakukan sebelumnya. Perbedaan penelitian ini dengan penelitian sebelumnya adalah objek penelitiannya yaitu konsumen produk KFC di Kota Denpasar. KFC dipilih karena merupakan restoran cepat saji yang menguasai pangsa pasar makanan siap saji di Indonesia dalam Top Brand Award tahun 2015-2016, tetapi menurut suvei awal terhadap 25 orang responden menyatakan tidak tertarik terhadap produk KFC sebanyak 62,5 persen karena citra merek yang ditawarkan terhadap variasi produk KFC yang dapat memenuhi kebutuhan makanan dengan baik belum sesuai dengan harapan yang dirasakan konsumen.

Konsumen cenderung akan memilih produk yang telah terkenal dan digunakan oleh banyak orang dari pada produk yang belum dikenalnya (Suki, 2013). Konsumen biasanya akan memilih produk yang lebih dikenalnya untuk dikonsumsi dari pada memilih produk yang sama sekali belum dikenal baik secara kualitas ataupun kinerja yang diberikan produk tersebut, hal ini disebabkan oleh 
kemungkinan resiko yang diterima akan lebih besar ketimbang produk yang sudah dikenal baik oleh konsumen. Suatu produk dengan citra merek yang kuat akan mempermudah produk tersebut dikenal konsumen sehingga akan menjadi suatu keunggulan tersendiri bagi produk tersebut untuk sampai ketangan konsumen.

Kotler dan Armstrong (2008:347) menyatakan bahwa:” Kualitas Produk adalah kemampuan suatu produk untuk melakukan fungsi-fungsinya yang meliputi daya tahan, keandalan, ketepatan, kemudahan, operasi, dan perbaikan serta atribut lainnya." Bila suatu produk sudah menjalankan fungsi-fungsinya dapat dikatakan sebagai produk yang memiliki kualitas yang baik." Produk yang ditawarkan perusahaan akan berpengaruh terhadap kegiatan perusahaan mulai dari mendesain, mengadakan sistem produksi dan operasi, menciptakan program pemasaran, sistem distribusi, iklan dan mengarahkan tenaga penjual untuk menjual. Secara umum definisi produk adalah segala sesuatu yang dapat ditawarkan kepasar untuk memenuhi kebutuhan konsumen. Menurut William. J Stanton dalam Alma (2004:139), Produk adalah seperangkat atribut yang berwujud maupun tidak berwujud termasuk didalamnya warna, harga, nama baik produk, nama baik toko yang menjual (pengecer) dan pelayanan pabrik serta pelayanan pengecer yang diterima oleh pembeli guna memuaskan kebutuhan dan keinginan. Sedangkan menurut Kotler (2005:84) produk yaitu segala sesuatu yang dapat ditawarkan untuk memuaskan suatu kebutuhan dan keinginan konsumen.

Citra merek adalah pandangan atau penilaian konsumen terhadap suatu merek yang baik ataupun buruk. Beberapa pendapat para ahli yang mendefinisikan citra merek antara lain: Menurut American Marketing Association (AMA) dalam Kotler 
Ida Bagus Dicky Darmajaya dan Tjok Gede Raka Sukawati, Peran Citra Merek...

\& Keller (2016:322) merek adalah tanda, simbol, atau rancangan dan kombinasi dari semuanya, yang memilki maksud untuk mengidentifikasi barang dan jasa penjual atau kelompok penjual dan untuk mendeferensiasikannya. Menurut Alma (2013:130) mengemukakan bahwa merek sebagai suatu tanda atau simbol yang memberikan identitas suatu barang atau jasa tertentu, dapat berupa kata-kata, gambar, atau kombinasi keduanya. Menurut Kartajaya (2010:62) merek sebagai asset yang menciptakan value bagi pelanggan dengan meningkatkan kepuasan dan menghargai kualitas. Brand image adalah seperangkat asosiasi unik di dalam pikiran pelanggan mengenai apa yang menjadi hak merek dan janji tersirat dari pembuat merek (Neupane, 2015). (Saeed et al., 2013) menyatakan bahwa pada perusahaan atau produk yang memiliki brand image yang baik cenderung akan memiliki superioritas di pasar, keunggulan kompetitif yang besar dan pangsa pasar yang dominan.

Citra merek memiliki arti suatu pencitraan sebuah produk dibenak konsumen secara massal. Persaingan dunia industri yang semakin ketat dari waktu ke waktu, menuntut perusahaan untuk selalu lebih kreatif dan menciptakan suatu keunggulan yang kompetitif, baik dari segi produk, kemasan, saluran pemasaran maupun citranya. Berdasarkan definisi-definisi yang telah dikemukakan diatas dapat disimpulkan bahwa pengertian merek adalah janji penjual kepada konsumen secara konsisten untuk memberikan manfaat dan jasa tertentu kepada konsumen serta merek terbaik akan memberikan jaminan kualitas.

Menurut Kotler dan Armstrong (2012:157)., "Consumer buyer behavior refers to the buying behavior of final consumers - individuals and households that 
buy goods and services for personal consumption", pengertian tersebut dapat diartikan bahwa perilaku keputusan pembelian mengacu pada perilaku pembelian akhir dari konsumen, baik individual, maupun rumah tangga yang membeli barang dan jasa untuk konsumsi pribadi. Menurut Kotler dan Keller (2009:240) menyatakan bahwa, "Keputusan pembelian adalah konsumen membentuk niat untuk membeli merek yang paling disukai."

Berdasarkan definisi-definisi tersebut, maka dapat diambil kesimpulan bahwa keputusan pembelian adalah perilaku konsumen untuk membeli suatu barang atau jasa yang mereka sukai atau pemilihan dari salah satu dari beberapa alternatif penyelesaian masalah yang dikumpulkan oleh seorang konsumen dan mewujudkan dengan tindak lanjut yang nyata. Setelah proses tersebut, barulah konsumen itu dapat mengevaluasi pilihannya dan menentukan sikap yang akan diambil selanjutnya.

Citra merek memiliki arti suatu pencitraaan sebuah produk dibenak konsumen secara massal, jika kualitas produk selalu ditingkatkan oleh perusahaan maka citra merek dari produk tersebut seiring berjalan waktu akan selalu meningkat. Penelitian yang dilakukan Nuraini dan Maftukhah (2015) pada penelitiannya menyatakan bahwa variabel kualitas produk berpengaruh terhadap citra merek. Noerchoidah (2013) menyatakan bahwa kualitas produk memiliki pengaruh terhadap citra merek. $\mathrm{H}_{1}$ : Kualitas produk berpengaruh positif dan signifikan terhadap citra merek.

Fuad Asshiddieqi (2012) menyatakan bahwa citra merek berpengaruh signifikan terhadap keputusan pembelian konsumen. Menurut Xuemei Bian dan 
Ida Bagus Dicky Darmajaya dan Tjok Gede Raka Sukawati, Peran Citra Merek...

Luiz Moutinho (2011) menyebutkan bahwa dimensi brand image yang dihasilkan oleh konsumen memiliki pengaruh terhadap keinginan konsumen untuk membeli dan pada akhirnya menghasilkan keputusan pembelian. Nanda Octaviana (2016) dari hasil penelitiannya yang membuktikan citra merek berpengaruh signifikan dan positif terhadap keputusan pembelian. Kemudian hasil penelitian yang dilakukan oleh Musay (2013) pada penelitiannya menyimpulkan bahwa citra merek berpengaruh secara signifikan terhadap keputusan pembelian. Hasil penelitian dari (Malik et al., 2013) menemukan bahwa citra merek mempunyai pengaruh yang positif dan signifikan dengan keputusan pembelian konsumen. $\mathrm{H}_{2}$ : Citra merek berpengaruh positif dan signifikan terhadap keputusan pembelian.

Kualitas produk berpengaruh signifikan terhadap keputusan pembelian konsumen. Indrayani (2013) memperlihatkan bahwa variabel kualitas produk memiliki pengaruh yang positif dan signifikan terhadap keputusan pembelian. Penelitian yang dilakukan oleh Budi Ningtyas dkk. (2010) yang menyimpulkan bahwa kualitas produk adalah salah satu dari berbagai faktor yang mempengaruhi keputusan pembelian. Lebih lanjut menurut Wendy Van Rijswijk (2006) menyatakan bahwa persepsi konsumen yang positif terhadap suatu kualitas produk sebuah makanan akan berdampak pada pilihan konsumen dalam keputusan pembelian. (Candra et al., 2014) Kualitas produk yang ada di dalam produk tersebut harus sesuai dengan apa yang diharapkan konsumen, dimana jika kualitas produk tersebut sesuai dengan yang diharapkan konsumen maka banyak konsumen yang menginginkan produk tersebut, sehingga terjadinya pembelian pada suatu produk. Hasil penelitian (Ninh et al., 2015) menunjukan bahwa kualitas produk 
memiliki pengaruh positif dan signifikan terhadap keputusan pembelian konsumen. (Tariq et al., 2013) juga menemukan bahwa kualitas produk berpengaruh positif dan signifikan terhadap keputusan pembelian konsumen $\mathrm{H}_{3}$ : Kualitas produk berpengaruh positif dan signifikan terhadap keputusan pembelian

Menurut Nurdianto dan Yuniati (2013) menyimpulkan bahwa kualitas produk mempunyai pengaruh secara langsung dan signifikan terhadap keputusan pembelian demikian juga saat dimediasi oleh citra merek. Karlina dan Seminari (2015) menyatakan bahwa citra merek berpengaruh langsung terhadap keputusan pembelian variabel citra merek. Penelitian yang dilakukan Idris (2013) menunjukkan hasil bahwa secara positif citra merek dan kualitas produk berpengaruh terhadap keputusan pembelian. $\mathrm{H}_{4}$ : Citra merek memediasi pengaruh kualitas produk terhadap keputusan pembelian.

\section{METODE PENELITIAN}

Penelitian ini menguji hipotesis yang menjelaskan pengaruh kualitas produk terhadap citra merek, pengaruh citra merek terhadap keputusan pembelian, pengaruh kualitas produk terhadap keputusan pembelian serta peran citra merek dalam memediasi hubungan antara kualitas produk terhadap keputusan pembelian.

Lokasi penelitian dilakukan di kota Denpasar, di mana lebih terpusat pada restoran-restoran cepat saji KFC di Kota Denpasar. Karena sebagai ibukota Provinsi Bali mobilitas penduduk Kota Denpasar cukup tinggi membuat masyarakatnya banyak memilih mengkonsumsi makanan yang cepat dan praktis didapat. Salah satu produk makanan cepat saji yang dikenal di Indonesia khususnya kota Denpasar adalah KFC dan juga merupakan pemimpin Top brand Award fast food tahun 2015- 
Ida Bagus Dicky Darmajaya dan Tjok Gede Raka Sukawati, Peran Citra Merek...

2016. Banyaknya restoran cepat saji di Kota Denpasar membuat banyak restoran cepat saji saling bersaing dalam mengedepankan kualitas produk dan citra merek yang nantinya akan membuat suatu keputusan pembelian pada konsumen.

Variabel eksogen (X), dalam penelitian ini yaitu Kualitas Produk .Variabel mediasi atau variabel intervening (M), dalam penelitian ini yaitu Citra Merek. Variabel endogen (Y) dalam penelitian ini yaitu Keputusan Pembelian.

Populasi dalam penelitian ini adalah seluruh masyarakat Kota Denpasar yang pernah melakukan pembelian produk KFC dalam 3 bulan terakhir. Sampel dalam penelitian ini adalah masyarakat di Kota Denpasar yang pernah melakukan pembelian produk KFC.

Pengambilan sampel dilakukan dengan teknik purposive sampling yaitu teknik penentuan sampel dengan pertimbangan tertentu (Sugiyono,2014:122). Kriteria sampel dalam penelitian ini adalah responden yang pernah melakukan pembelian produk KFC di Kota Denpasar dalam 3 bulan terakhir. Diharapkan sesuai dengan karakteristik tersebut maka responden telah mempunyai pengalaman terhadap produk KFC, memahami dan mengerti isi kuesioner sehingga dapat mengetahui dan mengukur tingkat peran citra merek memediasi kualitas produk terhadap keputusan pembelian. Penentuan ukuran sampel responden, untuk memperoleh hasil yang baik ukuran sampel responden yang diambil untuk mengisi kuesioner. Ferdinand (2002:47) mengatakan, jumlah sampel ideal 5-10 kali jumlah variabel atau indikator tertentu, karena jumlah indikator dalam penelitian ini sejumlah 11 buah, maka $11 \times 10=110$. Jadi ukuran sampel dalam penelitian ini adalah 110 sampel. 
Metode pengumpulan data dalam penelitian ini adalah dengan metode survey dengan menggunakan kuesioner. Kuesioner adalah teknik pengumpulan data yang efisien apabila peneliti tahu dengan siapa variabel akan diukur dan tahu apa yang bisa diharapkan dari responden (Sugiyono, 2014:142). Kuesioner digunakan untuk memperoleh data responden mengenai kualitas produk, citra merek, keputusan pembelian.

Teknik analisis data yang digunakan dalam penelitian ini adalah teknik analisis jalur (path analysis). Teknik analisis jalur ini dapat didefinisikan sebagai perluasan dari analisis linier berganda dalam memperkirakan hubungan kausalitas antara yang telah ditetapkan berdasarkan teori. Analisis jalur digunakan untuk menentukan hubungan 3 variabel atau lebih dalam mengkorfimasi dan menolak hipotesis (Ghozali, 2011:249).

Pengujian hipotesis mediasi dapat dilakukan dengan Uji Sobel (Sobel Test). Uji sobel digunakan untuk menguji kekuatan pengaruh tidak langsung variabel kualitas produk $(\mathrm{X})$ ke variabel keputusan pembeliann $(\mathrm{Y})$ melalui variabel citra merek (M). Pengaruh tidak langsung kualitas produk (X) terhadap variabel keputusan pemebelian (Y) melalui variabel citra merek (M).

Uji sobel dilakukan untuk menguji peran mediasi yang diberikan oleh variabel komitmen organisasional, maka pengujian signifikansi variabel mediasi dalam model dapat diperiksa dari hasil uji pengaruh tidak langsung. Berdasarkan pengujian ini dapat diteliti tingkat intervensi dari variabel mediasi apakah memediasi penuh (full mediation) atau memediasi sebagian (partial mediation) atau bukan mediasi. 
Ida Bagus Dicky Darmajaya dan Tjok Gede Raka Sukawati, Peran Citra Merek...

\section{HASIL PENELITIAN DAN PEMBAHASAN}

Berdasarkan klasifikasi jenis kelamin, hasil penelitian ini menunjukkan bahwa responden didominasi oleh laki-laki sebanyak 54,55\%, sedangkan perempuan sebanyak 45,45\%. Berdasarkan klasifikasi usia, hasil penelitian ini menunjukkan bahwa responden berusia $17-35$ tahun yaitu sebesar $67,27 \%$, dan responden berusia 36 - 50 tahun yaitu sebesar $32,73 \%$. Berdasarkan klasifikasi terakhir yaitu klasifikasi berdasarkan pendidikan terakhir yang didominasi oleh masyarakat yang memiliki tingkat pendidikan SMA/SMK yaitu sebesar 50,91\%, kemudian diikuti oleh masyarakat yang memiliki tingkat pendidikan D2/D3 yaitu sebesar $40 \%$, masyarakat yang memiliki tingkat pendidikan sarjana yaitu sebesar $9,09 \%$

Pengujian data dalam penelitian ini menggunakan teknik analisis jalur (Path Analysis), dimana analisis jalur adalah perluasan dari analisis regresi linear berganda untuk menguji hubungan kausalitas antara 2 atau lebih variabel. Tahapan melakukan teknik analisis jalur yaitu.

Perhitungan koefisien path dilakukan dengan analisis regresi melalui software SPSS 17.0 for Windows, diperoleh hasil yang ditunjukan pada Tabel 1.

Tabel 1.

Hasil Analisis Jalur Persamaan Regresi 1

\begin{tabular}{|c|c|c|c|c|c|c|c|}
\hline \multirow[b]{2}{*}{ Model } & & & \multicolumn{2}{|c|}{$\begin{array}{l}\text { Unstandardized } \\
\text { Coefficients }\end{array}$} & \multirow{2}{*}{$\begin{array}{c}\text { Standardized } \\
\text { Coefficients } \\
\text { Beta }\end{array}$} & \multirow[b]{2}{*}{$\mathbf{t}$} & \multirow[b]{2}{*}{ Sig. } \\
\hline & & & B & Std. Error & & & \\
\hline & (Constan & int) & 0.228 & 0.110 & & 2.067 & 0.041 \\
\hline & $\begin{array}{l}\text { Kualitas } \\
\text { produk }\end{array}$ & & 0.916 & 0.035 & 0.928 & 25.841 & 0.000 \\
\hline $\mathrm{R} 1^{2}$ & : & 0,861 & & & & & \\
\hline F Statistik & $:$ & 667,736 & & & & & \\
\hline Sig F & : & 0.000 & & & & & \\
\hline
\end{tabular}


Berdasarkan hasil analisis jalur substruktur 1 seperti yang disajikan pada Tabel 1 maka persamaan strukturalnya adalah sebagai berikut :

$$
\begin{aligned}
& M=\beta 1 X+e \ldots . \\
& M=0,928 X+e
\end{aligned}
$$

Nilai B1 adalah sebesar 0,928 memiliki arti bahwa kualitas produk berpengaruh positif terhadap citra merek, dengan kata lain jika kualitas produk meningkat maka citra merek akan meningkat sebesar 0,928 .

\section{Tabel 2.}

\begin{tabular}{|c|c|c|c|c|c|c|c|}
\hline & & & \multicolumn{2}{|c|}{$\begin{array}{l}\text { Unstandardized } \\
\text { Coefficients }\end{array}$} & \multicolumn{3}{|l|}{$\begin{array}{l}\text { Standardized } \\
\text { Coefficients }\end{array}$} \\
\hline \multicolumn{3}{|c|}{ Model } & B & $\begin{array}{l}\text { Std. } \\
\text { Error }\end{array}$ & Beta & $\mathbf{t}$ & Sig. \\
\hline \multirow[t]{3}{*}{1} & (Co & & 0.084 & 0.151 & & .557 & 0.579 \\
\hline & Kua & roduk & 0.503 & 0.127 & 0.477 & 3.951 & 0.000 \\
\hline & Citr & & 0.452 & 0.129 & 0.424 & 3.506 & 0.001 \\
\hline $\mathrm{R}_{2}^{2}$ & & $: 0,783$ & & & & & \\
\hline & istik & $: 192,542$ & & & & & \\
\hline & & $: 0,000$ & & & & & \\
\hline
\end{tabular}

Hasil Analisis Jalur Persamaan Regresi 2

Berdasarkan hasil analisis jalur substruktur 2 seperti yang disajikan pada Tabel 2 maka persamaan strukturalnya adalah sebagai berikut :

$$
\begin{gathered}
Y=\beta_{1} X+\beta_{2} M+e \ldots . \\
Y=0,477 X+0,424 M+e
\end{gathered}
$$

Nilai B1 adalah sebesar 0,477 memiliki arti bahwa kualitas produk berpengaruh positif terhadap keputusan pembelian, dengan kata lain jika kualitas produk meningkat maka keputusan pembelian akan meningkat sebesar 0,477. 
Ida Bagus Dicky Darmajaya dan Tjok Gede Raka Sukawati, Peran Citra Merek...

Nilai B2 adalah sebesar 0,424 memiliki arti bahwa citra merek berpengaruh positif terhadap keputusan pembelian, dengan kata lain jika citra merek meningkat maka keputusan pembelian akan meningkat sebesar 0,424.

Menguji nilai koefisien determinasi $\left(\mathrm{R}^{2}\right)$ dan variabel error (e) Berdasarkan model substruktur 1 dan substruktur 2, maka dapat disusun model diagram jalur akhir. Sebelum menyusun model diagram jalur akhir, terlebih dahulu dihitung nilai standar eror sebagai berikut:

$$
\begin{array}{r}
\mathrm{Pe}_{\mathrm{i}}=\sqrt{1-R 1^{2}} \ldots \ldots \ldots \ldots \ldots \ldots . . . . . . . . \\
\mathrm{Pe}_{1}=\sqrt{1-R 1^{2}}=\sqrt{1-0,861}=0,373
\end{array}
$$

(sebesar 37,3\% variabel kualitas produk tidak mampu menjelaskan variabel citra merek)

$$
\mathrm{Pe}_{2}=\sqrt{1-R 2^{2}}=\sqrt{1-0,783}=0,466
$$

(sebesar 46,6\% variabel kualitas produk dan citra merek tidak mampu menjelaskan variabel keputusan pembelian)

Berdasarkan perhitungan pengaruh error $\left(\mathrm{Pe}_{\mathrm{i}}\right)$, didapatkan hasil pengaruh error $\left(\mathrm{Pe}_{1}\right)$ sebesar 0,373 dan pengaruh error $\left(\mathrm{Pe}_{2}\right)$ sebesar 0,466.

Hasil koefisien determinasi total adalah sebagai berikut :

$$
\begin{aligned}
\mathrm{R}^{2}{ }_{\mathrm{m}} & =1-\left(\mathrm{Pe}_{1}\right)^{2}\left(\mathrm{Pe}_{2}\right)^{2} \ldots \ldots \\
& =1-(0,373)^{2}(0,466)^{2} \\
& =1-(0,139)(0,217) \\
& =1-0,030=0,970
\end{aligned}
$$


Nilai determinasi total sebesar 0,970 mempunyai arti bahwa sebesar 97\% variasi keputusan pembelian dipengaruhi oleh variasi kualitas produk dan variasi citra merek, sedangkan sisanya sebesar 3\% djelaskan oleh faktor lain yang tidak dimasukkan ke dalam model.

Koefisien jalur secara simultan (Uji F) Pada Tabel 2 ditampilkan pengujian goodness of fit melalui nilai F statistik dan Sig.F yang akan diterjemahkan melalui rumusan hipotesis statistik sebagai berikut:

Berdasarkan hasil pengujian Sig. F pada Tabel 2, yang dimana dihasilkan Sig. $\mathrm{F} \leq 0,05(0,000 \leq 0,05)$ maka $\mathrm{H}_{\mathrm{a}}$ diterima yaitu Kualitas produk dan Citra merek berpengaruh secara simultan dan signifikan terhadap keputusan pembelian. Kesimpulannya adalah bahwa model persamaan struktural telah memenuhi syarat goodness of fit melalui uji $\mathrm{F}$.

Pengaruh variabel secara parsial (Keseluruhan) berdasarkan hasil analisis pengaruh kualitas produk terhadap citra merek diperoleh nilai Sig. t sebesar 0,000 dengan nilai koefisien beta 0,928 . Nilai Sig. t $0,000<0,05$ mengindikasikan bahwa $\mathrm{H}_{0}$ ditolak dan $\mathrm{H}_{1}$ diterima. Hasil ini mempunyai arti bahwa kualitas produk berpengaruh positif dan signifikan terhadap citra merek produk KFC di Kota Denpasar

Pengaruh kualitas produk terhadap keputusan pembelian berdasarkan hasil analisis pengaruh kualitas produk terhadap keputusan pembelian diperoleh nilai Sig. t sebesar 0,000 dengan nilai koefisien beta 0,477. Nilai Sig. t 0,000<0,05 mengindikasikan bahwa $\mathrm{H}_{0}$ ditolak dan $\mathrm{H}_{1}$ diterima. Hasil ini mempunyai arti 
Ida Bagus Dicky Darmajaya dan Tjok Gede Raka Sukawati, Peran Citra Merek...

bahwa kualitas produk berpengaruh positif dan signifikan terhadap keputusan pembelian produk KFC di Kota Denpasar.

Pengaruh citra merek terhadap keputusan pembelian berdasarkan hasil analisis pengaruh citra merek terhadap keputusan pembelian diperoleh nilai Sig. $\mathrm{t}$ sebesar 0,001 dengan nilai koefisien beta 0,424. Nilai Sig. $t 0,001<0,05$ mengindikasikan bahwa $\mathrm{H}_{0}$ ditolak dan $\mathrm{H}_{1}$ diterima. Hasil ini mempunyai arti bahwa citra merek berpengaruh positif dan signifikan terhadap keputusan pembelian produk KFC di Kota Denpasar.

Tabel 3.

Pengaruh Langsung, Pengaruh Tidak Langsung serta Pengaruh Total kualitas produk(X), Citra merek (M), dan Keputusan pembelian (Y)

\begin{tabular}{cccc}
\hline $\begin{array}{l}\text { Pengaruh } \\
\text { Variabel }\end{array}$ & $\begin{array}{c}\text { Pengaruh } \\
\text { Langsung }\end{array}$ & $\begin{array}{c}\text { Pengaruh Tidak Langsung } \\
\text { Melalui Citra merek } \\
(\mathbf{M})=(\boldsymbol{\beta 1} \mathbf{x} \boldsymbol{\beta 3})\end{array}$ & $\begin{array}{c}\text { Pengaruh } \\
\text { Total }\end{array}$ \\
\hline $\mathrm{X} \rightarrow \mathrm{M}$ & 0.928 & - & 0.928 \\
$\mathrm{X} \rightarrow \mathrm{Y}$ & 0,477 & 0,393 & 0,870 \\
$\mathrm{M} \rightarrow \mathrm{Y}$ & 0,424 & - & 0.424 \\
\hline \multicolumn{2}{l}{ Sumber: Data Primer Diolah, 2018 }
\end{tabular}

Uji sobel merupakan alat analisis untuk menguji signifikansi dari hubungan tidak langsung antara variabel independen dengan variabel dependen yang dimediasi oleh variabel mediator. Uji Sobel dirumuskan dengan persamaan berikut dan dapat dihitung dengan menggunakan aplikasi Microsoft Excel 2007. Bila nilai kalkulasi Z lebih besar dari 1,96 (dengan tingkat citra merek 95 persen), maka variabel mediator dinilai secara signifikan memediasi hubungan antara variabel terikat dan variabel bebas. Penghitungan variabel mediasi menggunakan statistik uji.

$$
\mathrm{Z}=\frac{\mathrm{a}}{\sqrt{\mathrm{b}^{2} \mathrm{~S}_{\mathrm{a}}^{2}+\mathrm{a}^{2} \mathrm{~S}_{\mathrm{b}}^{2}+\mathrm{S}_{\mathrm{a}}^{2} \mathrm{~S}_{\mathrm{b}}^{2}}}
$$


Keterangan :

$$
\begin{aligned}
& \mathrm{a}=0,928 \\
& \mathrm{~S}_{\mathrm{a}}=0,035 \\
& \mathrm{~b}=0,424 \quad \mathrm{~S}_{\mathrm{b}}=0,129 \\
& Z=\frac{0,928.0,424}{\sqrt{\left(0,928^{2} 0,129^{2}\right)+\left(0,424^{2} 0,035^{2}\right)+\left(0,035^{2} 0,129^{2}\right)}} \\
& Z=\frac{0,393}{\sqrt{0.01433+0.00022+0,00002}} \\
& Z=\frac{0,3}{0,1} \\
& Z=3,260
\end{aligned}
$$

Hasil dari pengujian variabel mediasi yaitu citra merek didapatkan $\mathrm{Z}$ hitung sebesar 3,260> 1,96 yang berarti variabel mediasi yakni citra merek dinilai secara signifikansi memediasi pengaruh antara kualitas produk terhadap keputusan pembelian.

Pengujian hipotesis pada pengaruh kualitas produk terhadap citra merek menemukan pengaruh positif dari variabel kualitas produk terhadap citra merek dengan hasil (Sig. $\mathrm{t} \leq 0,05$ ) serta koefisien beta sebesar 0,928 yang menunjukkan bahwa kualitas produk berpengaruh positif dan signifikan terhadap citra merek KFC. Hal tersebut berarti bahwa semakin baik kualitas produk maka akan semakin tinggi tingkat citra merek KFC, sehingga hipotesis pertama dalam penelitian ini diterima.

Citra merek memiliki arti suatu pencitraaan sebuah produk dibenak konsumen secara massal, jika kualitas produk selalu ditingkatkan oleh perusahaan maka citra merek dari produk tersebut seiring berjalan waktu akan selalu 
Ida Bagus Dicky Darmajaya dan Tjok Gede Raka Sukawati, Peran Citra Merek...

meningkat. Penelitian yang dilakukan Nuraini dan Maftukhah (2015) pada penelitiannya menyatakan bahwa variabel kualitas produk berpengaruh terhadap citra merek. Noerchoidah (2013) menyatakan bahwa kualitas produk memiliki pengaruh terhadap citra merek.

Pengujian hipotesis pada pengaruh kualitas produk terhadap keputusan pembelian menemukan pengaruh positif dari variabel kualitas produk terhadap keputusan pembelian dengan hasil (Sig. $\mathrm{t} \leq 0,05$ ) serta koefisien beta sebesar 0,477 yang menunjukkan bahwa kualitas produk secara positif berpengaruh signifikan terhadap keputusan pembelian KFC. Hal tersebut berarti bahwa semakin baik kualitas produk maka akan semakintinggi tingkat keputusan pembelian, sehingga hipotesis kedua dalam penelitian ini diterima.

Fuad Asshiddieqi (2012) menyatakan bahwa citra merek berpengaruh signifikan terhadap keputusan pembelian konsumen. Menurut Xuemei Bian dan Luiz Moutinho (2011) menyebutkan bahwa dimensi brand image yang dihasilkan oleh konsumen memiliki pengaruh terhadap keinginan konsumen untuk membeli dan pada akhirnya menghasilkan keputusan pembelian. Nanda Octaviana (2016) dari hasil penelitiannya yang membuktikan citra merek berpengaruh signifikan dan positif terhadap keputusan pembelian.Kemudian hasil penelitian yang dilakukan oleh Musay (2013) pada penelitiannya menyimpulkan bahwa citra merek berpengaruh secara signifikan terhadap keputusan pembelian. Hasil penelitian dari (Malik et al., 2013) menemukan bahwa citra merek mempunyai pengaruh yang positif dan signifikan dengan keputusan pembelian konsumen. 
Pengujian hipotesis pada pengaruh citra merek terhadap keputusan pembelian menemukan pengaruh positif dari variabel citra merek terhadap keputusan pembelian dengan hasil (Sig. $\mathrm{t} \leq 0,05$ ) serta koefisien beta sebesar 0,424 yang menunjukkan bahwa citra merek berpengaruh positifdan signifikan terhadap keputusan pembelian. Hal tersebut berarti bahwa semakin baik citra merek maka akan semakin tinggi tingkat keputusan pembelian KFC, sehingga hipotesis ketiga dalam penelitian ini diterima.

Indrayani (2013) memperlihatkan bahwa variabel kualitas produk memiliki pengaruh yang positif dan signifikan terhadap keputusan pembelian. Penelitian yang dilakukan oleh Budi Ningtyas dkk. (2010) yang menyimpulkan bahwa kualitas produk adalah salah satu dari berbagai faktor yang mempengaruhi keputusan pembelian. Lebih lanjut menurut Wendy Van Rijswijk (2006) menyatakan bahwa persepsi konsumen yang positif terhadap suatu kualitas produk sebuah makanan akan berdampak pada pilihan konsumen dalam keputusan pembelian. (Candra et al., 2014) Kualitas produk yang ada di dalam produk tersebut harus sesuai dengan apa yang diharapkan konsumen, dimana jika kualitas produk tersebut sesuai dengan yang diharapkan konsumen maka banyak konsumen yang menginginkan produk tersebut, sehingga terjadinya pembelian pada suatu produk. Hasil penelitian (Ninh et al., 2015) menunjukan bahwa kualitas produk memiliki pengaruh positif dan signifikan terhadap keputusan pembelian konsumen. (Tariq et al., 2013) juga menemukan bahwa kualitas produk berpengaruh positif dan signifikan terhadap keputusan pembelian konsumen 
Ida Bagus Dicky Darmajaya dan Tjok Gede Raka Sukawati, Peran Citra Merek...

Pengujian hipotesis pada citra merek memediasi pengaruh kualitas produk terhadap keputusan pembelian dengan menggunakan Uji Sobel atau Sobel Test membuktikan bahwa peran citra merek secara signifikan memediasi pengaruh kualitas produk terhadap keputusan pembelian dengan hasil $\mathrm{z}=3,260>1,96$, sehingga hipotesis keempat dalam penelitian ini diterima.

Menurut Nurdianto dan Yuniati (2013) meyimpulkan bahwa kualitas produk mempunyai pengaruh secara langsung dan signifikan terhadap keputusan pembelian demikian juga saat dimediasi oleh citra merek. Karlina dan Seminari (2015) menyatakan bahwa citra merek berpengaruh langsung terhadap keputusan pembelian variabel citra merek. Penelitian yang dilakukan Idris (2013) menunjukkan hasil bahwa secara positif citra merek dan kualitas produk berpengaruh terhadap keputusan pembelian.

Implikasi hasil penelitian ini mencakup dua hal yaitu, implikasi teoritis dan implikasi praktis yang menekankan pada manfaat nyata dari hasil penelitian untuk meningkatkan keputusan pembelian KFC melalui kualitas produk yang baik serta persepsi citra merek yang baik. Beberapa hasil penelitian ini adalah sebagai berikut:

Hasil penelitian ini memberikan sebuah implikasi kepada perusahaan mengenai bagaimana pentingnya kualitas produk dan citra merek dapat memengaruhi keputusan pembelian konsumen di Kota Denpasar. Hasil yang diperoleh dari penelitian ini menunjukkan hubungan secara langsung antar variabel, salah satunya adalah variabel kualitas produk terhadap citra merek, hal ini menunjukkan bahwa semakin semakin tinggi kualitas produk maka akan semakin tinggi pula citra merek produk, maka akan berdampak baik juga bagi citra merek 
itu sendiri, selanjutnya terdapat hubungan secara langsung antar variabel citra merek terhadap keputusan pembelian, hal ini dapat diartikan hal tersebut berarti semakin tinggi citra merek produk maka akan semakin tinggi keputusan pembelian produk. Selain itu, terdapat juga pengaruh langsung pada variabel kualitas produk terhadap keputusan pembelian, ini dapat diartikan bahwa kualitas produk juga memengaruhi keputusan pembelian dari konsumen. Implikasi penelitian ini dapat menggambarkan bahwa kualitas produk dan citra merek yang baik sangat memengaruhi keputusan pembelian konsumen terhadap produk.

Berdasarkan pernyataan responden tentang KFC bahwa "produk KFC merupakan produk yang selalu berinovasi dalam variasi menu produknya" memilki nilai rata-rata tertinggi diantara keempat pernyataan mengenai kualitas produk. Berdasarkan hasil tersebut terbukti bahwa responden merasa bahwa produk KFC selalu berinovasi dalam variasi menu produknya, dengan begitu jika perusahaan ingin meningkatkan ketertarikan konsumen untuk membeli produk KFC harus selalu berinovasi dalam variasi menu produknya agar lebih beragam macam variasinya untuk semakin diminati konsumen, maka akan memberikan dampak yang positif yakni terhadap minat konsumen untuk melakukan keputusan pembelian.

Berdasarkan pernyataan responden tentang KFC bahwa "terdapat ciri-ciri khusus sehingga produk KFC mudah diingat" memiliki nilai rata-rata tertinggi diantara keempat pernyataan mengenai citra merek. Berdasarkan hasil tersebut terbukti bahwa responden merasa bahwa produk KFC memiliki ciri-ciri khusus yang mebedakannya dari produk pesaingnya, dengan begitu jika perusahaan ingin 
Ida Bagus Dicky Darmajaya dan Tjok Gede Raka Sukawati, Peran Citra Merek...

meningkatkan ketertarikan konsumen untuk membeli produk KFC sudah seharusnya memperhatikan ciri-ciri khusus yang membuat produk KFC memilki ciri khas yang berbeda dari pesaingnya untuk mudah dikenali, karena dari ciri khas dari suatu produk akan membuat produk tersebut semakin diminati konsumen maka akan memberikan dampak yang positif yakni terhadap minat konsumen untuk melakukan keputusan pembelian.

Berdasarkan pernyataan responden tentang KFC bahwa "kemungkinan saya membeli produk KFC sangat tinggi" memiliki nilai rata-rata tertinggi diantara ketiga pernyataan mengenai keputusan pembelian maka dapat disimpulkan konsumen membeli produk KFC karena adanya keinginan dan minat beli yang tinggi, maka dengan begitu dapat disimpulkan bahwa pernyataan tersebut memilki respon positif dari masyarakat terhadap produk KFC, yang berarti bahwa dukungan kualitas produk yang baik dan citra merek yang positif akan memunculkan keputusan pembelian untuk membeli produk KFC.

\section{SIMPULAN DAN SARAN}

Berdasarkan hasil analisis penelitian dan hasil pembahasan di atas, maka dapat ditarik simpulan sebagai berikut bahwa Kualitas produk berpengaruh secara positif dan signifikan terhadap Citra merek. Hal tersebut berarti semakin baik kualitas produk yang diberikan maka semakin tinggi tingkat citra merek yang dirasakan.

Kualitas produk berpengaruh positif dan signifikan terhadap keputusan pembelian. Hal tersebut berarti semakin baik kualitas produk yang diberikan maka semakin tinggi tingkat keputusan pembelian konsumen KFC. 
Citra merek berpengaruh positif dan signifikan terhadap keputusan pembelian Produk. Hal tersebut berarti semakin baik citra merek yang diberikan maka akan semakin tinggi tingkat keputusan pembelian konsumen KFC.

Citra merek mampu memediasi kualitas produk terhadap Keputusan pembelian. Hal tersebut berarti citra merek memediasi pengaruh kualitas produk ke keputusan pembelian secara parsial.

Berdasarkan simpulan tersebut, maka saran yang dapat disampaikan pada penelitian ini adalah Bagi pihak perusahaan kedepannya dari segi kualitas produk agar lebih memperhatikan kesegaran dan daya tahan agar produk tersebut bisa memenuhi kebutuhan makanan konsumen dengan baik, kemudian dari segi citra merek kedepannya agar lebih mencari keunggulan pada produknya dengan membuat produk tersebut berbeda dibandingkan dengan para pesaingnya yang membuat konsumen setia pada produk, dan yang terakhir dari segi keputusan pembelian kedepannya lebih memperhatikan harga pada produk agar sesuai dengan harapan dan daya beli konsumen.

Dalam penelitian dimasa mendatang perlu dipertimbangkan untuk menggunakan variabel lain seperti promosi, harga, kualitas pelayanan dan lain-lain yang dapat mempengaruhi keputusan pembelian.

Memperluas cakupan wilayah penelitian misalnya dengan mengambil lokasi fast food lain yang ada di Bali atau Indonesia sehingga penelitian dapat digeneralisasikan. 
Ida Bagus Dicky Darmajaya dan Tjok Gede Raka Sukawati, Peran Citra Merek...

\section{REFERENSI}

Ackaradejruangsri, P. 2013. The Effect Of Product Quality Attributes On Thai Consumers Buying Decision. Ritsumeikan Journal Of Asia Pasific Studies, 33 (1), 14-24.

Andreani, Taniaji, and Puspitasari. 2012. The Impact of Brand Image Towards Loyalty with Satisfaction as A mediator in Mc Donald's. Journal of management and entrepreneurship, 14 (1), 64-71.

Arslan, Muhammad., M. Phil. 2014. Impact of Brand Image and Service Quality on Consumer Purchase Intention: A Study of Retail Store in Pakistan. Research on Humanities and Social Sciences. 4 (22), 98-107.

Aditya Yessika Alana, Wahyu Hidayat, Handoyo Djoko. 2012. Pengaruh Citra Merek, Desain, dan Fitur Produk terhadap Keputusan Pembelian Handphone Nokia (Studi Kasus pada Mahasiswa Universitas Diponegoro). Jurnal Ilmu Administrasi Bisnis, 2 (2), 69-77.

Alma, Buchari. 2013. Manajemen Pemasaran Jasa. Bandung: Alfabeta.

Bian, Xuemei and Moutinho Luiz. 2011. The role of brand image, product involvement, and knowledge in explaining consumer purchase behaviour of counterfeits. European Journal of Marketing, 45 (1), 23-30.

Budi, M. Andi Setia. 2014. Peran Brand Image Atas Pengaruh Tayangan Iklan Televisi Terhadap Keputusan Pembelian. Jurnal Ilmu \& Riset Manajemen ,3 (12), 5-7.

Bhakar, S. S., S. Bhakar, S. Bhakar. 2012. Relationship Between Country Of Origin, Brand Image and Customer Purchase Intention. ApeejayStya University: Far East Research Cente journal of psychology and Business, 10 (2), 2547.

Fuad Asshiddieqi. (2012). Analisis Pengaruh Harga, Desain Produk, dan Citra Merek Terhadap Keputusan Pembelian (Studi Kasus pada Produk Crooz di Distro Ultraa Store Semarang). Diponegoro Journal Of Management, 1 (1), $1-9$.

Huda, P., Sujito. 2012. Pengaruh Produk dan Promosi Terhadap Keputusan Pembelian Asuransi Kerugian yang Dimediasi oleh Kepercayaan Nasabah (Studi Kasus Pada PT. Asuransi Kerugian Jasa Indonesia Cabang Semarang Tahun 2012). Jurnal Mahasiswa Q-MAN, 1 (3), 92-105. 
Idris, H.A. 2013. Pengaruh Kualitas Produk, Citra Merek, Harga Dan Promosi Terhadap Keputusan Pembelian Mobil Jenis Mpv Merek Toyota Kijang Innova Di Semarang. Diponegoro Journal Of Management, 2 (3), 40-49.

Jalilvand, Reza Mohammad. 2012. The effect of electronic word of mouth on brand image and purchase intention. Marketing Intelligence \& Planning, 30 (4), 460-476.

Kartajaya, Hermawan. 2010. Brand Operation The Official MIM Academy Course Book. Jakarta: Erlangga Group.

Kotler, P dan Gary A. 2011. Dasar-dasar Pemasaran. Edisi Kesembilan. Jilid I. Penerbit PT. Indeks Kel. Gramedia. Jakarta.

Kotler, P., dan Keller. 2009. Manajemen Pemasaran. Edisi Ketiga Belas. Jilid Kesatu. Erlangga. Jakarta.

Lin, Nan-Hong and Bih-Syah Lin. 2007. The Effect of Brand Image and Product Knowledge on Purchase Intention. Journal of International Managements Studies, 3 (2), 121-132.

Malik, M. E., Ghafoor, M. M., Iqbal, H. K., Ali, Q., Hunbal, H., Noman, M. 2013. Impact of Brand Image and Advertisement on Consumer Buying Behavior. World Applied Sciences Journal, 23 (1), 117-122.

Masitha, Agil Merry dan Heru Suprihadi. 2014. Pengaruh Harga, Variasi Produk, Ketidakpuasan Konsumen Dan Iklan Peaing Terhadap Perpindahan Merek. Jurnal Ilmu dan Riset Manajemen, 3 (1), 2-18.

Musay, Fransisca Paramitasari. 2013. Pengaruh Brand Image Terhadap Keputusan Pembelian (Survei pada Konsumen KFC Kawi Malang). Jurnal Administrasi Bisnis, 3 (2), 3-7.

Mufidah, Nur Lailatul. 2012. Pola Konsumsi Masyarakat Perkotaan. Jurnal Unair BioKultur, 1 (2), 157-178.

Nigam, A., and Kaushik, R. 2011. Impact of Brand Equity on Customer Purchase Decisions an Empirical Investigation with Special Reference to Hatchback Car Owners in Central Haryana. IJCEM International Journal of Computational Engineering \& management, 12 (1), 121-128.

Ninh N., Thi T., and Phuong A. 2015. The Impact of Marketing Mix Elements on Food Buying Behavior: A Study of Supermarket Consumers in Vietnam International Journal of Business and Management, 10 (10), 206-224. 
Ida Bagus Dicky Darmajaya dan Tjok Gede Raka Sukawati, Peran Citra Merek...

Nuraini, Alfiyah, dan Ida Maftukhah. 2015. Pengaruh Celebrity Endorser dan Kualitas Produk Terhadap Keputusan Pembelian Melalui Citra Merek Pada Kosmetik Wardah di Kota Semarang. Management Analysis Journal, 4 (2), 2252-6552.

Nurdianto, Dedi., dan Tri Yuniati. 2013. Pengaruh Kualitas Produk dan Citra Sebagai Variabel Intervening terhadap Keputusan Konsumen dalam Membeli Motor Honda. Jurnal Ilmiah dan Riset Manajemen, 2 (10), 1-29.

Nurhayati, Siti. 2017. Pengaruh Citra Merek, Harga Dan Promosi Terhadap Keputusan Pembelian Handphone Samsung Di Yogyakarta. JBMA, 4 (2), 23-39.

Neupane, Ramesh. 2015. The Effects Of Brand Image On Customer Satisfaction And Loyalty Intention In Retail Super Market Chain Uk, International Journal of Social Sciences and Management. 2 (1), 9-26.

Noerchoidah. 2013. Analisis Pengaruh Harga, Kualitas Produk Dan Iklan Terhadap Brand Image Dan Keputusan Pembelian Sepeda Motor Merek Kawasaki. Jurnal WIGA, 3 (1), 2088-0944.

Octaviona, Nanda. (2016). "Pengaruh Citra Merek dan Persepsi Harga Terhadap Keputusan Pembelian Gadget di Toko Suryaphone Samarinda "The Effect of Brand Image and Perceived Prices on Purchase Decision of Gadget in Suryaphone Shop, Samarinda”. Ejournal Psikologi, 4 (4), 397-407.

Oghojafor, Ladipo, Ganiyu. 2012. The Influence Of Product Attributes On Consumer Purchase Decision In The Nigerian Food And Beverage Industry : A Study Of Lagos Metropolis. American Journal Of Business And Management, 1 (1), 456-468.

Putri, A. E., Apriatni, E. P., dan Wijayanto, A. 2013. Pengaruh Perluasan Merek Dan Kualitas Produk Terhadap Keputusan Pembelian Sampo Dove Di Semarang. Diponegoro journal of social and politic, 2 (2), 1-6.

Rijswijk, Wendy Van. 2006. Consumer Perceptions of Food Quality and Safety and Their Relation to Traceability. Jurnal of Marketing British Food Journal, 110 (10), 1034-1046.

Saeed Rashid, Rab Nawaz Lodhi, Amna Mehmood, Urooj Ishfaque, Fareha Dustgeer, Amna Sami, Zahid Mahmood, Moeed Ahmad. 2013. Effect Of Brand Image on Brand Loyalty and Role Of Customer Satisfaction in it . World Applied Science Journal 26 (10),1364-1370. 
Suki, N. M. 2013. Students' demand for Smartphones: Structural relationships of product features, brand name, product price and social influence. Campus Wide Information Systems Emerald Journal. 30 (4), 236-248.

Supriyadi, Yuntawati Fristin, Ginanjar Indra K.N. 2016. Pengaruh Kualitas Produk Dan Brand Image Terhadap Keputusan Pembelian (Studi Pada Mahasiswa Pengguna Produk Sepatu Merek Converse Di Fisip Universitas Merdeka Malang). Jurnal Bisnis dan Manajemen, 3 (1), 60-72.

Tariq, M., Nawaz, M., Butt, H. and Nawaz, M. 2013, Customer Perceptions about Branding and Purchase Intention:A Study of FMCG in an Emerging Market. Journal of Basic and Applied Scientific Research, 3 (2), 340-347.

Tjiptono, Fandy \& Candra Gregorius. 2005. Service, Quality and Satisfaction, Andi, Yogyakarta. 